A RCHIWA, BIBLIOTEKI

I MUZEA KOŚCIELNE 111 (2019)

https://doi.org.10.31743/abmk.2019.111.27

DANIEL KIPER* - LUBLIN

\title{
POLSKIE ROZSTANIE Z UNIĄ GRECKOKATOLICKĄ NA WSCHODNICH RUBIEŻACH RZECZYPOSPOLITEJ
}

(Irena Wodzianowska, Zmierzch Unii. Struktury terytorialne i personalne Cerkwi greckokatolickiej $w$ drugiej połowie XVIII wieku na Bracławszczyźnie, Lublin-Tczew 2018, ss. 503).

Rok temu ukazała się publikacja poświęcona dziejom Cerkwi greckokatolickiej na Bracławszczyźnie, której nie sposób przeoczyć. Jej autorka od lat zajmuje się badaniami nad dziejami Kościoła katolickiego w Rosji oraz Cerkwi unickiej na terenach południowo-wschodniej części metropolii kijowskiej ${ }^{1}$. W swym dorobku posiada liczne publikacje, w tym obszerną monografię dotyczącą funkcjonowania Katolickiej Akademii Duchownej w Petersburgu w latach 1842-19182. Omawiana publikacja jest zaś owocem wieloletnich badań opartych na niełatwo dostępnych materiałach przechowywanych $\mathrm{w}$ archiwach rosyjskich, białoruskich, ukraińskich, litewskich i watykańskich.

Rozdział pierwszy monografii wprowadza czytelnika w skomplikowaną sytuację społeczno-polityczną Bracławszczyzny jako szczególnego obszaru wchodzącego w skład Rzeczypospolitej. Były to tereny od niepamiętnych czasów nękane wojnami, klęskami żywiołowymi i zagrożeniem najazdami tatarski-

* Daniel Kiper - dr nauk humanistycznych; asystent naukowy w Ośrodku ABMK;

e-mail: danielkiper572@gmail.com

https://orcid.org/0000-0003-3580-604X

${ }^{1}$ Zob. m.in. Greckokatolickie dekanaty błoński i puchowicki w latach 1783-1784, oprac. I. Wodzianowska, Sandomierz 2006; I. Wodzianowska, Zmiana przynależności wyznaniowej parafii unickich w latach 60. i 70. XVIII wieku na Prawobrzeżnej Ukrainie. Zarys problematyki, w: Kościót unicki w Rzeczypospolitej, red. W. Walczak, Białystok 2010, s. 235-255; taż, Funkcjonowanie parafii greckokatolickich $w$ województwie bracławskim w przededniu II rozbioru Rzeczypospolitej, „Teka Komisji Historycznej”, 11 (2014) s. 69-90; taż, Rozwój greckokatolickiej sieci parafialnej dekanatu kalnickiego w XVIII wieku, „Studia Geohistorica”, 2 (2014) s. 31-42.

2 I. Wodzianowska, Rzymskokatolicka Akademia Duchowna w Petersburgu, 1842-1918, Lublin 2007. 
mi. Tamtejsza ludność, poddawana wpływom prawosławia, z dużymi oporami i niekonsekwentnie przyjmowała zmiany konfesyjne, co przy dużym oddaleniuod władz centralnych powodowało trudności w trwałym zakorzenieniu się obrządku greckokatolickiego. Struktury unickie zatem od początku istnienia funkcjonowały tam na niepewnych podstawach. Dodatkowym czynnikiem, który wzmagał opór miejscowej ludności wobec Unii, były prześladowania, jakich doświadczył Kościół prawosławny na tym terenie po roku 1775, czyli po traktacie między Rosją a Polską dotyczącym wolności religijnej. Równocześnie dzięki administracyjnej polityce wyznaniowej Katarzyny II od lat 80 . XVIII wieku systematycznie rosła pozycja prawosławia w Rzeczypospolitej, aż momentu kiedy po drugim i trzecim rozbiorze obszar metropolii kijowskiej znalazł się w granicach imperium rosyjskiego. Dnia 6 września 1795 r. caryca wydała ukaz likwidujący wszystkie diecezje unickie na obszarach zaanektowanych przez Rosję.

W rozdziale drugim autorka skoncentrowała się na przedstawieniu rozwoju struktur dekanalnych na Bracławszczyźnie oraz tamtejszej sieci parafialnej. Zrekonstruowała proces tworzenia parafii od połowy lat 60 . XVIII wieku, uwzględniając także informacje na temat wyposażenia świątyń oraz bazę materialną poszczególnych parafii na przestrzeni kilku dekad. Pozwoliło to na dokonanie opisu rozmaitych form uposażenia placówek oraz wielkości beneficjów parochialnych na tle burzliwych dziejów politycznych tego regionu. Nie można mieć zastrzeżeń do ustaleń autorki odnośnie do liczby parafii, jak i skrupulatnie odnotowanego procesu kształtowania się granic parafialno-dekanlnych. Podobnie rzecz się ma, jeśli idzie o sposób prezentowania danych ujętych w zwięzłą, logiczną narrację. Wywód jest przez to klarowny i przekonujący.

Najciekawiej prezentuje się jednak rozdział trzeci monografii, stanowiący portret zbiorowy kleru unickiego. Autorka przygląda się duchowieństwu pod kątem pochodzenia społecznego i wykształcenia. Szczegółowo zostały omówione również kwestie prawne, na podstawie których funkcjonował Kościół greckokatolicki na omawianym obszarze, ze szczególnym uwzględnieniem prawa patronatu. Wątek ten jest o tyle istotny, że dotyczy nie tylko podstaw prawnych działalności poszczególnych placówek duszpasterskich, lecz także, a może przede wszystkim, praktyki stosowania instytucjonalnych rozwiązań w ówczesnej rzeczywistości społecznej. Tym samym otrzymujemy wartościowy przegląd unikatowych fenomenów pozwalający otworzyć nowe perspektywy dla wiedzy na temat zachowań duchownych oraz wiernych w sytuacji zagrożeń, niepewności, kryzysu. Na skutek napięć społecznych, podczas których często dochodziło do podpaleń, rabunków i rzezi, wykształcono szczególne strategie przetrwania polegające na kilkukrotnej zmianie przynależności konfesyjnej parafii unickich na przestrzeni kilku dekad. Taki stan rzutuje na całościowy obraz przemian wyznaniowych, które dokonywały się na całym terytorium metropolii kijowskiej, a w szczególności rywalizacji unicko-prawosławnych. Wszystkie te polityczno-kulturowe znalazły odzwierciedlenie w szczególnym rysie potrydenckiej religijności kleru na opisywanych terenach. 
Autorka nie straciła z oczu również relacji duszpasterskich z wiernymi, wnikliwie przeanalizowawszy je na podstawie wizytacji parafialnych. Stanowią one przedmiot ostatniego rozdziału książki. Aktywność duszpasterska, jej specyfika i efekty są zagadnieniami, które niełatwo zrekonstruować na podstawie zachowanych materiałów. Tym bardziej zatem należy podkreślić poprawną i obficie zilustrowaną analizę religijnych postaw wiernych dokonaną na podstawie uczestnictwa w praktykach religijnych, rozwijania kultu świętych, znajomości podstawowych prawd wiary, działalności bractw religijnych, szkół parafialnych itp. Wydaje się jednak, że na bazie materiału źródłowego ukazującego relacje między duchowieństwem a wiernymi można było dużo bardziej pogłębić refleksję nad religijnością tamtejszych wiernych. Rozdział ten wydaje się być słabszym ogniwem książki, choć gwoli usprawiedliwienia trzeba pamiętać, że celem monografii miało być przede wszystkim zrekonstruowanie sieci administracyjnej oraz obsady personalnej greckokatolickiego kleru Bracławszczyzny, a nie skupianie się na życiu religijnym chłopstwa. Niemniej jednak może warto byłoby prześledzić niektóre wątki w sposób bardziej pogłębiony, nieco bardziej zróżnicować techniki duszpasterskie narzucane odgórnie i skonfrontować je z przejawami żywiołowej, często pogańskich form religijności wiernych (np. przynoszenie do cerkwi tzw. kuflika jako ofiary za zmarłego). Jak interpretować fakt pojawiania się szeptuch, wróżek i znachorów w domach duchownych mimo surowych zakazów? Podejście to niewątpliwie wiązałoby się z ryzykiem wejścia na grunt studiów nad mentalnością, wydobyciem i zdefiniowaniem pewnych dyspozycji psychospołecznych ludności będącej przedmiotem badań. Takie stanowisko zapewne niosłoby ze sobą konieczność częściowej modyfikacji warsztatu metodologicznego. Wysiłek ten jednak z pewnością mógłby podnieść walor pracy i wzbogacić książkę o nowy element $\mathrm{w}$ wielowarstwowym pejzażu problemowym, jaki niosą ze sobą badania nad relacjami Kościołów i społeczeństw tamtej burzliwej epoki.

Na styku ortodoksji i ludowych praktyk dochodziło do uzgadniania pewnych wspólnych działań w ramach sprawowania kultu. Autorka wspomina m.in. o realnych i potencjalnych konfliktach związanych ze stosowanym przez różne grupy wyznaniowe kalendarzy (gregoriańskiego i juliańskiego) regulujących dni wolne od pracy ${ }^{3}$ czy też dylematy obchodzenia świąt w małżeństwach mieszanych ${ }^{4}$. Niezwykle ciekawe uwagi powstały na marginesie omawiania zjawisk związanych z kultem maryjnym, gdzie mowa o doniosłej roli ,sanktuariów” maryjnych w zakresie jeśli nie integracji, to jednak pewnych zbliżeń między ludnością katolicką obu obrządków a prawosławną. Utrzymywały się one jeszcze w XIX wieku. Całkowite zerwanie kontaktów nastąpiło dopiero pod koniec tego stulecia. Podobnie misje bazyliańskie łączyły zgodnie w miejscach kultu katolików obu obrządków. W rozważaniach na temat problemów duszpasterskich aż prosi się postawić pytanie o chrzty katolików obrządku wschodniego w świątyniach łacińskich i prawosławnych. Czy były takie praktyki, a jeśli tak, to gdzie i jak często? Wartym szerszego omówienia w kontekście prób ustalenia stanu znajomości podstawowych

${ }^{3}$ I. Wodzianowska, Zmierzch Unii. Struktury terytorialne i personalne Cerkwi greckokatolickiej w drugiej połowie XVIII wieku na Bracławszczyźnie, Lublin-Tczew 2018, s. 303-304.

${ }^{4}$ Tamże, s. 358. 
prawd wiary przez parafian jest casus ludności wołoskiej (mołdawskiej), z którą, jak sama autorka dowodzi, trudno było się niekiedy duchownym porozumieć. Należy zaznaczyć, że powyższe uwagi w niczym nie umniejszają wartości książki, są raczej zachętą do dyskusji niż głosem krytycznym.

Warto na koniec podkreślić wartościowe aneksy oraz mapy umieszczone na końcu książki, które przybliżają ułatwiają badaczom poruszanie się w skomplikowanej strukturze administracyjnej i personalnej kościoła unickiego. Stanowią one również podstawową bazę faktograficzną dla adeptów nauki historycznej zainteresowanych rozmaitymi aspektami życia mieszkańców Bracławszczyzny tego czasu, z całą jej różnorodnością kulturową i wyznaniową. Ponadto książka zawiera liczne, niezwykle cenne zestawienia statystyczne i tabelaryczne, a także wykazy cerkwi, kaplic, duchowieństwa unickiego. Mogą one stanowić posłużyć do prowadzenia badań porównawczych na temat struktur Kościoła greckokatolickiego na sąsiadujących obszarach. Stąd należy wysoko ocenić warsztat badawczy Autorki oraz sposób prezentacji wniosków płynących z analizy źródeł. Zmierzch Unii... niewątpliwie stanowi lekturę obowiązkową dla badaczy Kościoła greckokatolickiego tamtego czasu i terenu. Jest to jedna z najważniejszych pozycji, jakie napisano o dziejach kościoła unickiego w Rzeczypospolitej Obojga Narodów.

\section{BIBLIOGRAFIA}

Greckokatolickie dekanaty błoński i puchowicki w latach 1783-1784, oprac. I. Wodzianowska, Sandomierz 2006.

Wodzianowska Irena, Zmiana przynależności wyznaniowej parafii unickich w latach 60. i 70. XVIII wieku na Prawobrzeżnej Ukrainie. Zarys problematyki, w: Kościót unicki w Rzeczypospolitej, red. W. Walczak, Białystok 2010, s. 235-255.

Wodzianowska Irena, Funkcjonowanie parafii greckokatolickich $w$ województwie bracławskim w przededniu II rozbioru Rzeczypospolitej, „Teka Komisji Historycznej”, 11 (2014) s. 69-90.

Wodzianowska Irena, Rozwój greckokatolickiej sieci parafialnej dekanatu kalnickiego w XVIII wieku, ,Studia Geohistorica”, 2 (2014) s. 31-42

Wodzianowska Irena, Rzymskokatolicka Akademia Duchowna w Petersburgu, 1842-1918, Lublin 2007.

Wodzianowska Irena, Zmierzch Unii. Struktury terytorialne i personalne Cerkwi greckokatolickiej w drugiej połowie XVIII wieku na Bracławszczyźnie, Lublin-Tczew 2018, s. 303-304. 